\title{
'Via Media' vs. the Critical Path: Constructivism(s) and the Case of EU Identity
}

\author{
Zeynep Arkan \\ Hacettepe University
}

\begin{abstract}
The European Union's international identity is a theme that has attracted great scholarly interest in the last two decades, parallel to the increasing role of the Union as a global actor. This period has also witnessed the rise of constructivism as an approach in International Relations with a specific focus on the social nature of and ideational factors in international affairs. Many of the works published in this time frame have approached the topic of European Union identity from a constructivist perspective that focused on the outcomes of the identity construction process within the Union, drawing parallels between the processes of identity construction and dissemination in nation states and at the European level. This study, by differentiating between the critical and conventional constructivist accounts of identity, offers a discursive analysis of the European Union's identity that concentrates instead on the building blocks and evolution of the identity construction process within the Union. To this aim, it explores the ways in which the identity of the European Union has been represented in the foreign policy discourse originating from the Union's various institutions and leaders, based on a particular conception of 'Europe.'
\end{abstract}

Keywords: Identity, constructivism, critical constructivism, Europe, European Union

\section{Introduction}

Yosef Lapid noted in The Return of Culture and Identity in IR Theory that "[c]ulture and identity are staging a dramatic comeback in social theory and practice." ${ }^{1}$ Focusing on the reflections of this comeback in the discipline of International Relations (IR), he explained that it was the outcome of two interconnected developments: the transformation of the global order that took place and a critical scrutiny in the discipline of IR that this transformation brought about. ${ }^{2}$ Leaving aside the argument that this might be culture and identity's first true appearance in IR theory, it can be said that the resulting "moment of robust intellectual openness"3 provided scholars with an opportunity to rethink the existing categories of analysis and presented the possibility of an intellectual transformation in the discipline.

In this period, it was a number of alternative approaches, or "critical margins of the IR discipline" that derived their explanatory power from the significance they attributed to factors that were previously disregarded. ${ }^{4}$ The critique that many of these approaches brought

\footnotetext{
Zeynep Arkan, PhD. Lecturer, Department of International Relations, Hacettepe University. Email: zeynep.arkan@gmail com.

Yosef Lapid, "Culture's Ship: Returns and Departures in International Relations Theory," in The Return of Culture and Identity in IR Theory, eds. Yosef Lapid and Friedrich Kratochwil (Boulder, CO: Lynne Rienner, 1996), 3.

2 Lapid, "Culture's Ship," 3.

3 Robert Latham, "Moments of Transformation," Items 47 (1994): 8, quoted in Lapid, "Culture's Ship," 3.

4 Lapid, "Culture's Ship," 4.
} 
forward was not about what mainstream scholars did or said but instead what they ignored, namely, "the content and sources of state interests and the social fabric of world politics." Accordingly, these alternative approaches aimed to demonstrate that the conception of IR as portrayed and theorised by mainstream approaches failed to reveal certain aspects of international politics.

Within the framework of these alternative approaches, "one topic that seems to be flashing in neon is "identity"." Identity has usually been treated as a factor that deserves little attention, since mainstream approaches assumed "that all units in global politics have only one meaningful identity, that of self-interested states." The underlying neorealist and neoliberal assumption regarding the similarities between states and their motives for action in the international arena forced them to treat identity and interests of states as exogenous and given. ${ }^{8}$ Building on their rationalist foundations, both theories focused on changes in state behaviour rather than changes in the interests and identities of states, and assumed that states were, and remained, alike. ${ }^{9}$ Those critical of these mainstream approaches, however, argued that the analysis of identity as an intervening factor would contribute to a better understanding of international politics by improving the discipline's "proverbial toolbox."

The period that witnessed a growing interest in the theme of identity in IR also saw the rise of a unique case study: the European Union (EU) as a world power in the making. The growing influence of the EU as one of the key players in international politics, and its increasing visibility and relevance within and outside the borders of the Union have put the topics of the EU's nature, qualities, and actorness in the spotlight since the 1990s. This has resulted in a growing interest in the identity of the Union regarding its essence and impact at the European and global levels, not only in the framework of European Integration Studies, but also in IR. The EU was usually portrayed as an unprecedented political entity that had, or was attempting to construct, its own transnational identity above those of the individual Member States. It was assumed that this transnational identity affected not only European citizens as a new form of collective identification, but also the Member States and the Union itself in their relations with the wider world.

This article aims to analyse the representations through which the EU, as a distinctive international actor, constructed its identity in its foreign policy discourse within the framework of its Common Foreign and Security Policy (CFSP) from a critical constructivist perspective. It will be argued that, instead of a conventional constructivist framework, a critical constructivist approach would not only help uncover the building blocks and key themes of this identity, but also demonstrate how representations of this identity evolved over the years. To this aim, the article will first briefly introduce the core assumptions of

\footnotetext{
Jeffrey T. Checkel, "The Constructivist Turn in International Relations Theory," World Politics 50, no.2 (1998): 324.

6 Marysia Zalewski and Cynthia Enloe, "Questions about Identity in International Relations," in International Relations Theory Today, eds. Ken Booth and Steve Smith (Cambridge: Polity, 1995), 280.

Ted Hopf, "The Promise of Constructivism in International Relations Theory," International Security 23, no.1 (Summer 1998): 175.

8 John Gerard Ruggie, Constructing the World Polity: Essays on International Institutionalization (New York: Routledge, 1998), 13.

9 Cynthia Weber, International Relations Theory: A Critical Introduction (New York: Routledge, 2005), 63.

10 Yosef Lapid, "Introduction: Identities, Borders, Orders: Nudging International Relations Theory in a New Direction," in Identities, Orders, Borders: Rethinking International Relations Theory, eds. Mathias Albert, David Jacobson and Yosef Lapid (Minneapolis, MN: University of Minnesota Press, 2001), 3.
} 
constructivism and explore how different variants within constructivism approached the topic of identity. It will then present a review of the constructivist literature on EU identity, highlighting the ways in which the critical constructivist approach could contribute to the existing debate. The final part of the article offers a critical constructivist analysis of EU identity that focuses particularly on the core concept of 'Europe' that dominated the Union's foreign policy discourse, and illustrates its evolution since the early days of the process of political integration in Europe.

\section{Constructivism and its Rise in the late $1990 \mathrm{~s}$}

Among the alternative approaches that came to the fore in the 1990s, constructivism occupies a central place in terms of its focus on previously disregarded aspects of IR, namely the importance of ideational factors and the social nature of international affairs. Constructivism is also one of the main approaches that offered a comprehensive account of the formation and impact of identity in international relations, as well as its linkages to interests and actions.

As an approach in social theory, constructivism is a way of studying social relations based on "a social ontology which insists that human agents do not exist independently from their social environment and its collectively shared systems of meanings." ${ }^{11}$ Building on this, constructivism as an IR approach also embraces a social ontology, yet deals with larger social collectivities, usually in the form of states. Constructivists argue that as social beings, agents shape and are in turn shaped by the social structures in which they are situated. In this respect, constructivism challenges the assumption that the formation of states' identities, interests, and preferences is prior and exogenous to social interaction.

For constructivists, though the international system includes both material and ideational factors, the former acquire meaning only through the latter. Thus, in contrast to mainstream scholars' 'desocialised' understanding of material factors, it is argued that "material resources only acquire meaning for human action through the structure of shared knowledge in which they are embedded." 12 Constructivists assume that the social structures in which material and ideational factors are embedded are defined by shared meanings and intersubjective understandings. If a certain social structure exists, it is because agents make it real and act in accordance with it. This implies that social structures exist "not in actors' heads nor in material capabilities, but in practices." ${ }^{13}$ Parallel to this, for constructivists, key concepts in the discipline of IR that shape theoretical and empirical debates are not fixed givens. These concepts, not only in the form of agents' interests and identities, but also those that define the international system, such as anarchy, "are reified structures that were once upon a time conceived ex nihilo by human consciousness."14

In the constructivist framework, identity proved to be a topic that was discussed extensively from a number of different perspectives. While these perspectives adhered to the same underlying assumptions, they differed from each other in terms of how they approached the process of social construction and the methods they used in their analyses.

${ }^{11}$ Thomas Risse, "Social Constructivism and European Integration," in European Integration Theory, eds. Thomas Diez and Antje Wiener (New York: Oxford University Press, 2004), 160.

12 Alexander Wendt, "Constructing International Politics," International Security 20, no.1 (Summer 1995): 73.

13 Wendt, "Constructing International Politics," 74.

${ }^{14}$ Emanuel Adler, "Seizing the Middle Ground: Constructivism in World Politics," European Journal of International Relations 3, no.3 (1997): 322; Alexander Wendt, "Anarchy is what States Make of it: The Social Construction of Power Politics," International Organization 46, no.2 (Spring 1992): 391-425. 


\subsection{Constructivism(s) and identity}

In the 1990s, the rise of alternative approaches to world politics led to a reconceptualisation of the founding principles and existing categories in the discipline of IR. This contributed to an intensified debate between two rival camps - rationalism and reflectivism - regarding the foundations of the study of world politics. Approaches that were built on rationalist foundations sought to explain behavioural regularities and causal mechanisms at work by examining the nature of the international system. ${ }^{15}$ These approaches presupposed the existence of an international political reality and neutral facts regarding this reality waiting to be discovered through the systematic use of scientific methods. On the other hand, reflectivists used interpretative and non-positivist methods to study what they regarded as intersubjective or intertextual structures, institutions, and understandings in international politics. They assumed that facts and actions, as well as political reality, do not speak for themselves; instead, "they have to be narrated and interpreted in meaningful ways within a particular social, cultural and historical context."16 This understanding implied that the focus of reflectivist approaches was not so much on determining the 'real causes' of events by establishing causal relationships between various factors and the resulting behaviour, but studying how specific interpretations of these events were made possible and came to dominate all others.

Following its introduction to the discipline of IR from social theory, constructivism was often described as occupying a middle ground between rationalist and reflectivist approaches. In fact, in an attempt to distinguish themselves from reflectivists, a number of leading constructivists such as Adler and Wendt argued that constructivism, through its emphasis on the ontological reality of intersubjective knowledge and its rationalist epistemological and methodological foundations, should be assigned the role of facilitating a conversation between the two sides. ${ }^{17}$ They argued that constructivism formed a 'via media' between rationalist and reflectivist positions based on the premise that "while the ideational aspect of human social life has important implications for international politics, these do not include a rejection of 'science'.", 18

Yet, the adherence of these leading constructivists to rationalist and positivist principles in their attempt to find a middle way proved to be a point of disagreement in the overall constructivist camp. The problem with the via media version of constructivism was that it disregarded a number of different positions within the constructivist camp, including those that were much closer to reflectivism. Zehfuss noted that only those who adopted the 'thinner' via media version that was in debate with rationalism were regarded as "proper constructivists." "19 Those who preferred 'thicker' versions of constructivism, on the other hand, were generally overlooked. ${ }^{20}$

\footnotetext{
${ }^{15}$ Robert Keohane, International Institutions and State Power: Essays in International Relations Theory (Boulder, CO: Westview, 1989), 8 .

16 Richard Jackson and Matt McDonald, "Constructivism, US foreign policy and the 'war on terror'," in New Directions in US Foreign Policy, eds. Inderjeet Parmar, Linda B. Miller and Mark Ledwidge (New York: Routledge, 2009), 18; Ole Wæver, "The rise and fall of the inter-paradigm debate," in International theory: positivism and beyond, eds. Steve Smith, Ken Booth and Marysia Zalewski (Cambridge: Cambridge University Press, 1996), 164.

17 Adler, "Seizing the Middle Ground," 322-323; Wendt, "Anarchy”; Maja Zehfuss, Constructivism in International Relations: The Politics of Reality (Cambridge: Cambridge University Press, 2002), 5.

18 Alexander Wendt, "On the Via Media: a response to the critics," Review of International Studies 26 (2000): 165-180.

19 Zehfuss, Constructivism in International Relations, 6.

${ }_{20}$ Maja Zehfuss, "Constructivism and Identity: A Dangerous Liaison," European Journal of International Relations 7, no.3 
While there is no commonly accepted categorisation of these different strands of constructivism, it is possible to analyse the constructivist programme as roughly divided into two: conventional and critical. ${ }^{21}$ While these two accounts agree on the fundamentals such as the need to 'denaturalise' the social world to reveal the human agency behind it, the key role played by shared understandings and meanings in the construction of social reality, and the mutual constitution of agency and structure, they differ from each other mainly in terms of their methodology and epistemology. ${ }^{22}$

What can be classified as conventional constructivism occupies the middle ground between rationalism and reflectivism, has an intersubjective ontology, and a positivist epistemology and methodology based on hypothesis testing and causality. ${ }^{23}$ Conventional constructivists adhere to the assumption that an objective reality exists out there, which can be understood and explained through scientific methods. Conventional constructivists believe "in the possibility of attaining empirical knowledge without the mediation of language" and assume that objects exist independently of the meanings attached to them. ${ }^{24}$

Conventional constructivists have a similar research agenda to that of mainstream IR theory, which focuses on explaining state behaviour. They differ from mainstream scholars, however, in terms of the importance they attach to ideational factors in shaping state behaviour. In fact, constructivists such as Ruggie, Adler, Katzenstein, Risse-Kappen, and Wendt aim to prove that ideational factors such as norms, rules, values, and identity, which are overlooked by mainstream approaches, have causal or semi-causal effects on state behaviour. Through its emphasis on "how ideational or normative structures constitute agents and their interests," this version of constructivism differs from mainstream theories only in terms of its ontology, but not its epistemology or methodology. 25

While agreeing with conventional constructivists on the matter of ontology, critical constructivists distinguish themselves through their focus on discourse, as well as their criticism of the former's reification of the state as the main object of analysis. The critical constructivist agenda that emerged in the late 1990s is founded upon the assumption that key

${ }^{21}$ It is difficult to draw strict boundaries between conventional and critical constructivism, and between critical constructivism and poststructuralism, as "both boundary drawings are to a significant extent a question of overlapping zones rather than insurmountable differences." Barry Buzan and Lene Hansen, The Evolution of International Security Studies (Cambridge: Cambridge University Press, 2009), 197. For more information on the different categorisations of constructivism, see Bahar Rumelili, "Constructing identity and relating to difference: understanding the EU's mode of differentiation," Review of International Studies 30, no.1 (January 2004): 27-47; Iver B. Neumann, Uses of the other: 'The East' in European identity formation (Manchester: Manchester University Press, 1999); Ronald L. Jepperson, Alexander Wendt and Peter J. Katzenstein, "Norms, Identity, and Culture in National Security," in The Culture of National Security: Norms and Identity in World Politics, ed. Peter J. Katzenstein (New York: Columbia University Press, 1996), 33-75; Richard Price and Christian Reus-Smit, "Dangerous Liaisons? Critical International Theory and Constructivism," European Journal of International Relations 4, no.3 (1998): 259-294; Hopf, “The Promise of Constructivism”; K.M. Fierke, "Constructivism," in International Relations Theories: Discipline and Diversity, eds. Tim Dunne, Milja Kurki and Steve Smith (New York: Oxford University Press, 2010), 177-194; Buzan and Hansen, The Evolution of International Security Studies; Adler, "Seizing the Middle Ground"; Emanuel Adler, "Constructivism and International Relations," in Handbook of International Relations, eds. Walter Carlsnaes, Thomas Risse and Beth A. Simmons (London: SAGE, 2007), 95-118.

22 Hopf, "The Promise of Constructivism," 182. Recent manifestations of the 'practice turn' in IR aim to bridge the divide between these various different constructivisms and other approaches, including poststructuralism and realism, by developing an 'interparadigmatic research programme'. By focusing on what is broadly termed as practices (linguistic or otherwise), and thereby going beyond traditional levels of analysis, IR scholars of this persuasion study world politics as structured by international practices. This, however, does not surmount the key points of diversion that exist between various constructivisms in IR. For various reflections of the 'practice turn' in IR, see Emanuel Adler and Vincent Pouliot, International Practices (Cambridge: Cambridge University Press, 2011); Chris Brown, "The 'Practice Turn', Phronesis and Classical Realism: Towards a Phronetic International Political Theory," Millennium: Journal of International Studies 40, no.3 (2012): 439-456; Iver B. Neumann, "Returning Practice to the Linguistic Turn: The Case of Diplomacy," Millennium: Journal of International Studies 31, no.3 (2002): 627-651.

23 Fierke, "Constructivism," 183-184.

24 Adler, "Constructivism and International Relations," 97; Fierke, "Constructivism," 185.

25 Peter J. Katzenstein, Robert O. Keohane and Stephen D. Krasner, "International Organization and the Study of World Politics," International Organization 52, no.4 (Autumn 1998): 675. 
objects of and concepts in the discipline of IR, such as 'national interest,' are not neutral, but are discursively constructed "through representations (of countries, peoples, etc.) and linguistic elements (nouns, adjectives, metaphors and analogies). ${ }^{26}$ To explore how these concepts are constructed, critical constructivists engage in detailed studies of texts to understand the systems of meaning and representation in discourse.

In their analyses, critical constructivists are more pluralistic than their conventional counterparts in terms of methodology, which includes post-positivist methods such as discourse analysis. They are also "deeply skeptical of the possibility of formulating general covering laws." ${ }^{27}$ Critical constructivists do not, however, deny the existence of a material world and assume, by differentiating between ontological objectivity and subjectivity, that it is only social reality that is constructed, not the natural one, and that discourse is essentially constitutive of the former. ${ }^{28}$ The key distinction between conventional and critical constructivism lies not in their assumptions regarding the existence of an objective world, but in the latter's emphasis on language as an intermediary between the signifier and the signified, the word and the thing. ${ }^{29}$ Material reality exists, yet its meaning is established through discourse. Parallel to this, issues in world politics as well as subjects and their actions are dependent on discourse, as outside it they do not acquire meaning. For critical constructivists, meaning is created through the interactions between agents on an intersubjective basis. In this vein, meaning is not an individual or collective but a social phenomenon: "it is not that everyone has the same 'ideas' inside their heads, but rather that meaning inheres in the practices and categories through which people engage with each other and with the natural world." ${ }^{30}$

The differences between conventional and critical constructivism have a considerable impact on their respective accounts of identity. The conventional constructivist account of identity focuses on the social practices that produce particular identities and assumes that it is possible to identify a specific "set of conditions under which one can expect to see one identity or another." 31 Conventional constructivists also argue that particular identities imply certain actions and interests. To explore how specific identities shape agents' actions and interests, they approach identity as an end product of the social practices of agents, as somewhat finalised and stable.

As opposed to this view, critical constructivists have a discursive approach to identity. Instead of linking identities to specific behavioural patterns, they are more concerned with how people come to identify with a certain identity and its associated narratives. They also focus on how agents draw on these identities to justify certain (foreign) policies instead of identifying the effects of these identities. Critical constructivism therefore "aims at exploding the myths associated with identity formation, whereas conventional constructivists wish to treat those identities as possible causes of action." ${ }^{32}$

Another key difference between these two accounts of identity relate to the dynamics

26 Buzan and Hansen, The Evolution of International Security Studies, 198.

7 Katzenstein, Keohane and Krasner, "International Organization," 676.

28 John R. Searle, The Construction of Social Reality (London: Penguin, 1995).

29 Fierke, "Constructivism," 185.

30 Jutta Weldes, Mark Laffey, Hugh Gusterson and Raymond Duvall, "Introduction: Constructing Insecurity," in Cultures of Insecurity: States, Communities, and the Production of Danger, eds. Jutta Weldes, Mark Laffey, Hugh Gusterson and Raymond Duvall (Minneapolis, MN: University of Minnesota Press, 1999), 13.

31 Hopf, "The Promise of Constructivism," 183.

32 Ibid., 183-184. 
of the process of identity construction. Conventional constructivists deal with how states acquire specific identities in the process of "interaction with other states; they come to see themselves and each other in terms of the subject positions that are constituted by the social structure of international politics." ${ }^{33}$ Critical constructivists, on the other hand, focus on the role played by practices of 'othering' in the process of identity construction. Accordingly, the critical constructivist identity requires the existence of an Other, as it is regarded incomplete without it. As opposed to this thinking, the conventional constructivist account is based on the construction of identity in social relations and does not require the existence of an Other. In fact, conventional constructivists assume that positive identification with the Other would eventually lead to the construction of collective identities on a larger scale. ${ }^{34}$ Weldes argued that, by assuming state identities are formed only through inter-state interaction, Wendt (and other conventional constructivists) treated the state "as a black box whose internal workings are irrelevant to the construction of state identities and interests. ${ }^{35}$ She explained that

[t]he meanings that objects, events, and actions have for states are necessarily the meanings they have for those individuals who act in the name of the state. And these state officials do not approach international politics with a blank slate onto which meanings are only written as a result of interactions among states. ${ }^{36}$

Instead, these officials act on the basis of their interpretations of these objects, events and actions, which are based on cultural raw materials and extant resources provided by the security imaginary of a state. In line with the critical constructivists' assumption that objects and events do not present themselves directly to the observer and that they need to be interpreted, it is argued that the linguistic as well as cultural resources that form an actor's security imaginary also define its identity as well as its interests, preferences, and actions.

In terms of its key assumptions, the critical constructivist account of identity is in some ways similar to the poststructuralist one, particularly regarding the role of discursive practices in the constitution of identity. Both approaches highlight the inherent link between identity and foreign policy: "Foreign policy problems, and especially acute problems, or 'crises,' are political acts, not facts; they are social constructions forged by state officials in the course of producing and reproducing state identity." ${ }^{37}$ Every subject 'performs' its identity in its relations with its external realm through its foreign policy. By focusing on the performative production of identity through foreign policy, critical constructivist scholars thereby distinguish themselves from conventional constructivists who presuppose the existence of an already formed state identity that precedes and shapes foreign policy. Another key resemblance between the critical constructivist and poststructuralist approaches regards the dynamics of identity construction. Like poststructuralists, critical constructivists attach great importance to practices of othering in the construction of identity, as "[a]lterity and difference are central to the processes by which individuals, groups or states build a sense of identity in the contrast between themselves and others." 38

33 Rumelili, "Constructing identity and relating to difference," 31

34 See Alexander Wendt, Social Theory of International Politics (Cambridge: Cambridge University Press, 1999). Wendt argued that through co-operation and interaction, states can form a collective identity and collective interests "which will in turn help them overcome the collective action problems that beset egoists." Ibid., 337.

35 Jutta Weldes, Constructing National Interests: The United States and the Cuban Missile Crisis (Minneapolis, MN: University of Minnesota Press, 1999), 9.

36 Weldes, Constructing National Interests.

37 Ibid., 219

38 K.M. Fierke, Critical Approaches to International Security (Cambridge: Polity, 2007), 77. 
Consequently, though the two different versions of constructivism are based on similar foundations, the accounts they offer, particularly in relation to construction and reproduction of identity, differ from each other in terms of the role attributed to discourse and the dynamics of identity construction. It can be concluded that critical constructivists offer a much more nuanced understanding that aims to explain how specific identities are produced, reproduced, or altered through the discursive practices of the agents, while conventional constructivists focus on the causal or semi-causal impact of identity on state behaviour.

\section{The Construction of EU Identity in Foreign Policy}

\subsection{Constructivism(s) and EU identity: The state of the art}

The ideas of conventional constructivists, particularly in terms of the gradual formation of collective identities, served as a source of inspiration for many studies on EU identity. ${ }^{39}$ Building on these ideas, scholars explored how the identity of the EU is constructed "in the course of social interaction; through encounters with other actors and in the context of the external environment of institutions and events which enable and constrain EU action" and acquired through internalisation or socialisation by the citizens of the Union. ${ }^{40}$ By establishing linkages between how identities at the national and European levels are constructed, studies drew parallels between the processes of nation formation and the creation of a 'European demos' within the EU, and assumed that a collective identity was imperative for the Union to function and survive. In line with this, they focused on the different methods through which this identity is constructed in the various policy areas and initiatives of the EU, and the effects of the process of integration and EU identity on the identities, policies, and domestic structures of Member and Candidate States under the heading of Europeanisation. ${ }^{41}$

A number of constructivist studies also suggested that the EU, as a value-based polity, is a new type of international actor with an identity that is not based on exclusion, providing non-members with the possibility of drawing closer to it by adopting its values and norms. In one of the most cited examples of this view, Manners, focusing on the ideational impact of the EU's international identity, categorised the Union as a normative power whose identity is based on the core norms of peace, liberty, democracy, the rule of law, and respect for human rights and fundamental freedoms. ${ }^{42}$ In latter works, Manners, Whitman and a number of other scholars focused on the co-constitution of role representations of the EU and polity perspectives, and explored how the identity of the EU is constructed at the international level and influences its external relations. ${ }^{43}$

39 See, for example Jeffrey T. Checkel and Peter J. Katzenstein (eds.), European Identity (New York: Cambridge University Press, 2009); Cris Shore and Annabel Black, "Citizens' Europe and the Construction of European Identity," in The Anthropology of Europe: Identity and Boundaries in Conflict, eds. Victoria A. Goddard, Josep R. Llobera and Cris Shore (Providence, RI: Berg, 1994), 275-298; Lars-Erik Cederman, Nationalism and Bounded Integration: What It Would Take to Construct a European Demos, EUI Working Papers 34 (2000); Cris Shore, "Inventing the 'People's Europe: Critical Approaches to European Community 'Cultural Policy'," Man 28, no.4 (1993): 779-800; Isabelle Petit, "Mimicking History: The European Commission and Its Education Policy," World Political Science Review 3, no.1 (2007): 1-25.

40 Charlotte Bretherton and John Vogler, The European Union as a Global Actor (New York: Routledge, 2006), 38-39.

${ }^{41}$ See, for example Monica Sassatelli, "Imagined Europe: The Shaping of a European Cultural Identity Through EU Cultural Policy," European Journal of Social Theory 5, no.4 (2002): 435-451; Anabelle Littoz-Monnet, The European Union and culture: Between economic regulation and European cultural policy (Manchester: Manchester University Press, 2007); Thomas Risse, "The Euro Between National and European Identity," Journal of European Public Policy 10, no.4 (2003): 487-505; Elizabeth Meehan, Citizenship and the European Community (London: SAGE, 1993).

42 Ian Manners, "Normative Power Europe: A Contradiction in Terms?," Journal of Common Market Studies 40, no.2 (2002): 235-258.

43 Ian Manners and Richard G. Whitman, "The 'difference engine': constructing and representing the international identity of the European Union," Journal of European Public Policy 10, no.3 (June 2003): 380-404; Richard G. Whitman, (ed.), Normative 
As opposed to conventional constructivism, the critical constructivist perspective has not had a considerable impact on studies on EU identity. While a limited number of scholars focused on the role of discourse in the EU's governance and political order, with respect to EU identity, analyses from this perspective were few. In one of the rare self-proclaimed critical constructivist works on identity, Rumelili dealt with the EU's different modes of differentiation in the constitution of its identity. She argued that, by emphasising the significance of difference in the constitution of identity and meaning, and the performative constitution of identity, critical constructivism offered a valuable alternative to what she labelled as liberal constructivism, as put forward by Wendt, Checkel, Finnemore, and Sikkink. ${ }^{44}$ In a similar tone, Diez argued that in the process of differentiating itself from its Others, the EU used various forms of othering. He maintained that in articulations of the EU as a normative power, the Union used various strategies from approaching the Other as an existential threat to viewing the Other as merely different from the Self. ${ }^{45}$

Consequently, the conventional constructivist framework proved to be the most commonly used perspective to study the gradual construction of collective identity at the European level. This monopoly was maintained despite the rise of alternative perspectives that focused on the role discourse plays in the constitution and maintenance of identities. The dominance of conventional constructivism eventually led to a 'conceptual overstretch,' within the framework of which identity became a gap-filler in the academic and public discourse, often leading to "a myriad of options for interpretation and misinterpretation," particularly in the absence of a clear research agenda and methodological guidelines on the part of conventional constructivism. ${ }^{46}$ This study argues that the critical constructivist approach would contribute to the existing debate not only in terms of demonstrating the evolution of the process of identity construction, but also by revealing the key building blocks upon which the EU's identity project is founded. To this aim, it offers an analysis of the EU's foreign policy discourse with a particular focus on the core concept of 'Europe' and the way it is represented in relation to the EU.

\subsection{A critical constructivist analysis of EU identity}

An actor's foreign policy is the key sphere in which that actor defines itself in relation to its various Others and performs its identity, thereby reproducing a specific narrative of this identity. As a unique type of international actor, the EU has a wide array of policy areas whose aims and impact can be classified under external relations, including trade and aid. Yet, the EU's political relations with its external realm (or in a narrower sense of the term, its foreign policy) are best encapsulated in the CFSP and its predecessor, the European Political Co-operation (EPC). It was through this policy area that various discursive agents within the EU, such as representatives of the Union's institutions, the High Representative, and leaders of Member States, defined the EU as a key global player in international politics and carved it a distinctive role to play. Therefore, it is not surprising to find that the only direct reference to the identity of the Union in its Founding Treaties is in relation to the CFSP, the main battleground of the EU's identity.

\footnotetext{
Power Europe: Empirical and Theoretical Perspectives (New York: Palgrave Macmillan, 2011).

44 Rumelili, "Constructing identity and relating to difference."

45 Thomas Diez, "Constructing the Self and Changing Others: Reconsidering 'Normative Power Europe'," Millennium 33, no.3 (2005): 613-636.

46 Heiko Walkenhorst, The Conceptual Spectrum of European Identity - From Missing Link to Unnecessary Evil, Limerick Papers in Politics and Public Administration 3 (2009), 2.
} 
The following paragraphs analyse the EU's identity representations in its foreign policy discourse (originating from various EU institutions and representatives) as the key discursive agents in the process of identity construction. The texts analysed include policy documents, commissioned reports, speeches, and declarations, and are assessed through a Foucauldian discourse analysis that focuses on the key representations that together form the many facets of the EU's identity. ${ }^{47}$ The assumption here is that the EU's identity project is a fluid and multi-faceted one that builds on various representations of what the EU stands for in the world, and the roles and qualities attributed to it. Accordingly, the analysis of the foreign policy texts focuses on how the discursive agents within the EU constructed the identity of the Union in relation to a specific conception of 'Europe' as the core concept and the symbolic reference on which this identity is built. In line with the argument that foreign policy debates, though composed of a number of individual texts, share and converge around a smaller number of core themes, it is concluded that the core concept of 'Europe,' which was often used interchangeably with the EU and identified through a systematic reading of the policy texts, serves as the main foundation upon which EU identity is built. ${ }^{48}$ Through its focus on the core concept of 'Europe' as simultaneously a geographical, cultural, and historic entity, this study not only aims to explore the key building blocks of the EU's identity, but also explain the evolution of the concept of 'Europe' as a formative theme in the Union's identity.

\subsubsection{The $E U$ and the changing conception of 'Europe'}

As a concept, 'Europe' has been ascribed a vital role as a 'vehicle of identity production' for the EU. ${ }^{49}$ It was the concept that was deemed to best symbolise what the EU stood for and represented in the international arena, and define how it was to behave in its foreign policy. The analysis of the EU's foreign policy texts demonstrated that the meaning of the term 'Europe' fluctuated in the EU discourse over time. In most cases, it was used almost synonymously with the EU (for example, in the form of 'European unification,' 'European unity,' 'construction of Europe,' or the 'idea of Europe'), which implied that the Union's identity also assumed different meanings parallel to the way in which the concept of 'Europe' was defined..$^{50}$

Spatially, the dominant conception of 'Europe' was by and large limited to the Member States of the European Community (EC)/EU. ${ }^{51}$ At the same time, its borders were flexible in the sense that they were open to other states that might, in the future, join the EC/EU. Parallel to this understanding, it was argued that whilst the EC "remain[ed] the original nucleus from which European unity has been developed and intensified," its enlargement to include the "other countries of this continent...would undoubtedly help the Communities to grow." 52

47 For more details, see Gavin Kendall and Gary Wickham, Using Foucault's Methods (London: SAGE, 1999).

48 Lene Hansen, Security as Practice: Discourse Analysis and the Bosnian War (Abingdon: Routledge, 2006 ), 51.

49 Ole Wæver, "Identity, communities and foreign policy: Discourse analysis as foreign policy theory," in European Integration and National Identity: The challenge of the Nordic states, eds. Lene Hansen and Ole Wæver (London: Routledge, 2002$), 24$.

50 In other cases, 'Europe' ostensibly referred to a geographical entity, a continent or region, whose specific borders remained vague.

51 A few references to a broader and seemingly geographical conception of 'Europe' often seemed straightforward and neutral. A clear example of this was the geographical precondition for membership to the EC: Article 237 of the Treaty of Rome stipulated that "(a)ny European State may apply to become a member of the Community." However, keeping in mind that that there is no commonly accepted geographical definition of 'Europe' in the Founding Treaties or elsewhere, it can be concluded that the 'Europeanness' of a state was in fact open to interpretation and was by no means neutral.

52 "Final Communiqué of the Conference of Heads of State or Government on 1-2 December 1969 at The Hague," accessed March 21, 2014, http://www.ena.lu/final_communique_hague_summit_december-1969-2-1565. 
In this respect, the EC/EU was usually assigned the role of a leader in its region, and the ultimate protector of the heritage, values, and norms that 'Europe' was based on. It was also represented as the greatest contributor to the current state of good relations and peace in the region, as it was assumed that the continent "has changed, partly because of the Union's successes" and its "contribution to an unprecedented period of peace and prosperity." 53

The commonalities that formed the basis of 'Europe' were defined on the basis of its continuous existence throughout history - a shared past, present and future - and defined the parameters of 'Europe's relations with the outside world. In terms of the historical dimension of these commonalities, there were various references to the common cultural heritage and responsibilities of the 'European' states in addition to a number of references to a common 'European' civilisation in the early texts. The Dooge Report, for example, argued that the promotion of common values of civilisation was one of the priorities on the path to establishing a Union, taking into account that " $[t]$ he contemplated European Union will not rest on an economic community alone." ${ }^{54}$ The Report further stated that "European culture is one of the strongest links between the States and peoples of Europe. It is part of the European identity." 55 In terms of the responsibilities that accompanied such a historical legacy, particular attention was paid to the role 'Europe' could play in the improvement of the relations between the East and the West, possibly in the form of a mediator and facilitator, and the historical links that existed between a number of Member States and their former colonies. It was also argued that a more united 'Europe' should be "capable of assuming the responsibilities incumbent on it by virtue of its political role, its economic potential and its manifold links with other peoples." 56

In these early texts, frequent references were also made to the common values, norms, and principles that formed the basis of 'Europe', which were often linked to the shared heritage of the Member States. As an example, in the statement issued following their meeting in Bonn, Member State leaders justified the motive to form the union of 'Europe' based on "the spiritual values and political traditions which form their common heritage" and "the awareness of the great tasks which Europe is called upon to fulfil within the community of free peoples in order to safeguard liberty and peace in the world." ${ }^{57}$ In the same vein, the 1970 Luxembourg Report on the future of foreign policy co-operation stated that "[a] united Europe should be based on a common heritage of respect for the liberty and rights of man and bring together democratic States with freely elected parliaments." 58 These 'European' norms and values in the form of democracy, the rule of law, social justice, and respect for human rights laid the foundations of the present political reality of 'Europe' and brought the Member States together as a community.

In the period that followed the establishment of the CFSP in 1992, references to the 'civilisational' commonalities that brought the peoples and states of 'Europe' together became less frequent. Only a limited number of texts, mostly originating from individual

\footnotetext{
53 "Report by the Reflection Group: A Strategy for Europe," accessed March 12, 2014, http://www.ena.lu/report_reflection_ group_strategy_europe_brussels_december_1995-3-19371.

${ }_{54}$ Ad hoc Committee for Institutional Affairs, "Report to the European Council, Brussels, 29-30 March 1985," accessed February 20, 2014, http://aei.pitt.edu/997/01/Dooge_final_report.pdf, 18.

55 Ibid., 20.

56 "Solemn Declaration on European Union, Stuttgart, 19 June 1983," accessed February 20, 2014, http://www.ena.lu/solemn declaration_european_union_stuttgart_19_june_1983-2-7725.

57 "Statement Issued by the Heads of State or Government, Bonn," Bulletin of the European Communities 7, no.8 (1961): 35.

58 "Report by the Foreign Ministers of the Member States on the Problems of Political Unification," Bulletin of the European Communities No. 11 (1970): 9.
} 
representatives of the EU, mentioned the Member States' underlying cultural and spiritual commonalities and highlighted the need to take further action to defend and promote them in the Union's external sphere. Some of these commonalities were derived from a shared 'European' history, as in the case of "a civilisation deeply rooted in religious and civic values." 59 Others originated from 'Europe's shared history and informed the current form, goals, and relations of the EU, as well as its future. These remarks were accompanied by increasingly frequent references to the norms, values, and principles that the EU is considered to be built upon, in the form of democracy, the rule of law, respect for human rights, and fundamental freedoms. The Union was thus represented as a 'community of values,' membership to which was open only to those who shared a commitment to them.

In this period, references to a broader and almost hierarchical conception of 'Europe' also became somewhat more frequent, which corresponded to the changes taking place in the region following the end of the Cold War. Now 'Europe' included Central and Eastern European countries as well as the Baltic States in the form of prospective Member States. Yet, these countries were sometimes referred to as the 'other Europe,' different from what was possibly perceived as the 'real Europe,' i.e., the existing and mainly Western Member States. The relationship between the existing Member States and this 'other Europe' was not clearly defined. A number of texts referred to the countries of the 'other Europe' as part of the larger 'European family' despite their different experiences and histories, while other texts talked about the responsibility of the EU to unite, or reunite, 'Europe,' implying that there was no real separation between its constituent parts. A number of documents even mentioned "overcoming the divisions of Europe and restoring the unity of the continent whose peoples share a common heritage and culture," highlighting a deeper level of historical unity between the different parts of 'Europe.' ${ }^{\circ}$

In the last decade of the CFSP, references to the 'European' norms, values, and principles (respect for human rights and fundamental freedoms, democracy, the rule of law and equality) were present in almost all of the texts. These notions were also seen as forming the core of the EU's foreign policy, and in parallel, the Union was given the responsibility to uphold and promote them in its relations with the wider world:

The Union's action on the international scene shall be guided by the principles which have
inspired its own creation, development and enlargement, and which its seeks to advance in
the wider world: democracy, the rule of law, the universality and indivisibility of human
rights and fundamental freedoms, respect for human dignity, the principles of equality and
solidarity, and respect for the principles of the United Nations Charter and international law. ${ }^{61}$

In this period, references to the common cultural and civilisational foundations of 'Europe' were almost non-existent, as agents chose instead to define the building blocks of the EU's identity in the form of its shared 'European' values, norms, and principles, possibly as a response to the increasingly heterogeneous composition of the Union and its changing international context.

It can be concluded that in the EU's foreign policy discourse, the meaning of 'Europe,' as the core concept on which the EU's identity is built, has varied. In many of the texts

59 Romano Prodi, “2000-2005: Shaping the New Europe,” Speech given at the European Parliament, Strasbourg, 15 February 2000, Speech/00/41, 2 .

60 "Dublin European Council Presidency Conclusions, 15 and 16 June 1990," accessed April 22, 2014, http://www.europarl. europa.eu/summits/dublin/du1_en.pdf, 10.

${ }_{61}$ Treaty of Lisbon, Article 1/24, 23 
analysed, the term 'Europe' was used almost interchangeably with the EC/EU. Therefore, the borders of 'Europe' roughly corresponded to those of the EC/EU. This 'Europe', however, was not a geographical unit. Instead, it was represented as a historic entity based on a set of commonalities, which formed the building blocks of the EU's identity. These commonalities, as well as the temporal dimension of this conception of 'Europe,' were portrayed in a continuous manner, linking the shared past of 'Europe,' its present reality, and its common future. Similarly, in the early texts that originated from the European Council, EU representatives, and experts' committees, 'Europe' was represented as built on a common civilisation, culture, history, and heritage, features of which were reflected in the present reality of the Union. The commonalities that brought together the states and peoples of 'Europe' also included shared objectives, interests, ideals, values, and principles. These commonalities were then linked to the future of 'Europe' in the form of a common destiny for its states and peoples.

This view of 'Europe' as a historic entity united by a cultural and civilisational heritage, however, did not survive the 1990s; the focus turned to the normative foundations of 'Europe' in the form of the values, norms, and principles its identity was based upon, and the standards it aimed to uphold in its relations with the wider world. This in turn was reflected in the way in which the EU was defined as a global actor, whose identity and foreign policy behaviour were themselves defined by the EU's commitment to democracy, the rule of law, respect for human rights and fundamental freedoms, respect for human dignity, and the principles of equality and solidarity. This normative facet of the identity of 'Europe' today best describes what the EU stands for in the world and shapes its relations with its external realm despite its limitations as a foreign policy actor.

\section{Conclusion}

As an approach in IR, constructivism offers a comprehensive account of the social nature of world politics. By approaching identity as a social construct produced and reproduced through the interactions of agents, constructivism puts forward a set of means through which identity can be conceptualised and analysed in international affairs. Yet it would be wrong to treat constructivism as a cohesive and unitary approach in IR. Instead, it can roughly be divided into two quite distinct perspectives - conventional and critical constructivism - that share a core number of assumptions, but, at the same time, diverge from each other in terms of methodology and epistemology. It is argued in this study that while the conventional account is helpful in understanding the impact of identity in international affairs, it fails to provide a satisfactory account of how the dynamics of the process of identity construction operate. The critical constructivist account, on the other hand, focuses on the discursive processes through which identity is constructed and adopts a more pluralistic methodology to study the dynamics of construction and reproduction.

By adopting a critical constructivist approach to identity, this article aimed to illustrate how the identity of the EU was constructed in its foreign policy discourse in relation to the concept of 'Europe.' It was argued that representations of this core concept illustrated the foundations upon which the EU's identity was built. The term 'Europe' was often used synonymously with the EC/EU in foreign policy discourse. This 'Europe' was initially portrayed an entity founded upon a shared history in the form of a unique civilisation with a shared cultural and humanistic heritage. These common historical features of 'Europe' were 
then linked to its present through the values, norms, and principles derived from its history in the form of democracy, the rule of law, respect for human rights and fundamental freedoms, equality, and social justice, as well as the common interests and responsibilities of its states and peoples. The EU was also projected into the future in the form of the common destiny of these states and peoples. This conception of 'Europe' was represented in a temporally continuous manner, as an entity that has existed throughout history in an almost uninterrupted form and, as such, symbolising the foundations upon which the EU is built.

Changes in the EU's composition and structure, as well in its international context, implied that such an exclusive, cultural, and civilisational view of 'Europe' was no longer feasible. Therefore, the last two decades have witnessed a shift in the way in which 'Europe' was conceptualised. In this period, 'Europe' came to be characterised as founded upon a core set of values, norms, and principles derived from its history and reflected in its present political reality. These concepts, commitment to which is identified as one of the preconditions for membership into the Union, today form the basis of the EU's identity and make the EU a defender of these values and norms in not only its neighborhood but also the wider world.

\section{Bibliography}

Ad hoc Committee for Institutional Affairs. "Report to the European Council, Brussels, 29-30 March 1985." Accessed February 20,2014. http://aei.pitt.edu/997/01/Dooge_final_report.pdf.

Adler, Emanuel and Vincent Pouliot, eds. International Practices. Cambridge: Cambridge University Press, 2011.

Adler, Emanuel. "Constructivism and International Relations." In Handbook of International Relations, edited by

Walter Carlsnaes, Thomas Risse and Beth A. Simmons, 95-118. London: SAGE, 2007.

Adler, Emanuel. "Seizing the Middle Ground: Constructivism in World Politics." European Journal of International Relations 3, no.3 (1997): 319-363.

Bretherton, Charlotte and John Vogler, The European Union as a Global Actor. New York: Routledge, 2006.

Brown, Chris. "The 'Practice Turn', Phronesis and Classical Realism: Towards a Phronetic International Political Theory.” Millennium: Journal of International Studies 40, no.3 (2012): 439-456.

Buzan, Barry and Lene Hansen. The Evolution of International Security Studies. Cambridge: Cambridge University Press, 2009.

Cederman, Lars-Erik. Nationalism and Bounded Integration: What It Would Take to Construct a European Demos. EUI Working Papers 34 (2000).

Checkel, Jeffrey T. "The Constructivist Turn in International Relations Theory.” World Politics 50, no.2 (1998): 324-348.

Checkel, Jeffrey T. and Peter J. Katzenstein, eds. European Identity. New York: Cambridge University Press, 2009.

Diez, Thomas. "Constructing the Self and Changing Others: Reconsidering 'Normative Power Europe'.” Millennium 33, no.3 (2005): 613-636.

Fierke, K.M. “Constructivism.” In International Relations Theories: Discipline and Diversity, edited by Tim Dunne,

Milja Kurki and Steve Smith, 177-194. New York: Oxford University Press, 2010.

Fierke, K.M. Critical Approaches to International Security. Cambridge: Polity, 2007.

Hansen, Lene. Security as Practice: Discourse Analysis and the Bosnian War. Abingdon: Routledge, 2006.

Hopf, Ted. "The Promise of Constructivism in International Relations Theory." International Security 23, no.1 (Summer 1998): 171-200.

Jackson, Richard and Matt McDonald. "Constructivism, US foreign policy and the 'war on terror'." In New Directions in US Foreign Policy, edited by Inderjeet Parmar, Linda B. Miller and Mark Ledwidge, 18-31. New York: Routledge, 2009. 
Jepperson, Ronald L., Alexander Wendt and Peter J. Katzenstein. "Norms, Identity, and Culture in National Security." In The Culture of National Security: Norms and Identity in World Politics, edited by Peter J. Katzenstein, 33-75. New York: Columbia University Press, 1996.

Katzenstein, Peter J., Robert O. Keohane and Stephen D. Krasner. "International Organization and the Study of World Politics.” International Organization 52, no.4 (Autumn 1998): 645-685.

Kendall, Gavin and Gary Wickham. Using Foucault's Methods. London: SAGE, 1999.

Keohane, Robert. International Institutions and State Power: Essays in International Relations Theory. Boulder, CO: Westview, 1989.

Lapid, Yosef. "Introduction: Identities, Borders, Orders: Nudging International Relations Theory in a New Direction.” In Identities, Orders, Borders: Rethinking International Relations Theory, edited by Mathias Albert, David Jacobson and Yosef Lapid, 1-20. Minneapolis, MN: University of Minnesota Press, 2001.

Lapid, Yosef. “Culture's Ship: Returns and Departures in International Relations Theory.” In The Return of Culture and Identity in IR Theory, edited by Yosef Lapid and Friedrich Kratochwil, 3-20. Boulder, CO: Lynne Rienner, 1996.

Littoz-Monnet, Anabelle. The European Union and culture: Between economic regulation and European cultural policy. Manchester: Manchester University Press, 2007.

Manners, Ian and Richard G. Whitman. "The 'difference engine': constructing and representing the international identity of the European Union.” Journal of European Public Policy 10, no.3 (June 2003): 380-404.

Manners, Ian. "Normative Power Europe: A Contradiction in Terms?.” Journal of Common Market Studies 40, no. 2 (2002): 235-258.

Meehan, Elizabeth. Citizenship and the European Community. London: SAGE, 1993.

Neumann, Iver B. "Returning Practice to the Linguistic Turn: The Case of Diplomacy." Millennium: Journal of International Studies 31, no.3 (2002): 627-651.

Neumann, Iver B. Uses of the other: 'The East' in European identity formation. Manchester: Manchester University Press, 1999

Petit, Isabelle. "Mimicking History: The European Commission and Its Education Policy." World Political Science Review 3, no.1 (2007): 1-25.

Price, Richard and Christian Reus-Smit. "Dangerous Liaisons? Critical International Theory and Constructivism." European Journal of International Relations 4, no.3 (1998): 259-294.

Prodi, Romano. "2000-2005: Shaping the New Europe." Speech given at the European Parliament, Strasbourg, 15 February 2000, Speech/00/41.

Risse, Thomas. "Social Constructivism and European Integration." In European Integration Theory, edited by Thomas Diez and Antje Wiener, 159-176. New York: Oxford University Press, 2004.

Risse, Thomas. "The Euro Between National and European Identity." Journal of European Public Policy 10, no.4 (2003): 487-505.

Ruggie, John Gerard. Constructing the World Polity: Essays on International Institutionalization. New York: Routledge, 1998.

Rumelili, Bahar. "Constructing identity and relating to difference: understanding the EU's mode of differentiation." Review of International Studies 30, no.1 (January 2004): 27-47.

Sassatelli, Monica. "Imagined Europe: The Shaping of a European Cultural Identity Through EU Cultural Policy." European Journal of Social Theory 5, no.4 (2002): 435-451.

Searle, John R. The Construction of Social Reality. London: Penguin, 1995.

Shore, Cris and Annabel Black. "Citizens' Europe and the Construction of European Identity." In The Anthropology of Europe: Identity and Boundaries in Conflict, edited by Victoria A. Goddard, Josep R. Llobera and Cris Shore, 275-298. Providence, RI: Berg, 1994.

Shore, Cris. "Inventing the 'People's Europe: Critical Approaches to European Community 'Cultural Policy'." Man 28, no.4 (1993): 779-800. 
Wæver, Ole. "Identity, communities and foreign policy: Discourse analysis as foreign policy theory." in European Integration and National Identity: The challenge of the Nordic states, edited by Lene Hansen and Ole Wæver, 20-49. London: Routledge, 2002.

Wæver, Ole. "The rise and fall of the inter-paradigm debate." In International theory: positivism and beyond, edited by Steve Smith, Ken Booth and Marysia Zalewski, 149-185. Cambridge: Cambridge University Press, 1996.

Walkenhorst, Heiko. The Conceptual Spectrum of European Identity - From Missing Link to Unnecessary Evil, Limerick Papers in Politics and Public Administration 3 (2009).

Weber, Cynthia. International Relations Theory: A Critical Introduction. New York: Routledge, 2005.

Weldes, Jutta, Mark Laffey, Hugh Gusterson and Raymond Duvall. "Introduction: Constructing Insecurity." In

Cultures of Insecurity: States, Communities, and the Production of Danger, edited by Jutta Weldes, Mark Laffey, Hugh Gusterson and Raymond Duvall, 1-33. Minneapolis, MN: University of Minnesota Press, 1999.

Weldes, Jutta. Constructing National Interests: The United States and the Cuban Missile Crisis. Minneapolis, MN: University of Minnesota Press, 1999.

Wendt, Alexander. "On the Via Media: a response to the critics.” Review of International Studies 26 (2000): 165-180. Wendt, Alexander. Social Theory of International Politics. Cambridge: Cambridge University Press, 1999.

Wendt, Alexander. "Constructing International Politics." International Security 20, no.1 (Summer 1995): 71-81.

Wendt, Alexander. "Anarchy is what States Make of it: The Social Construction of Power Politics." International Organization 46, no.2 (Spring 1992): 391-425.

Whitman, Richard G., ed. Normative Power Europe: Empirical and Theoretical Perspectives. New York: Palgrave Macmillan, 2011.

Zalewski, Marysia and Cynthia Enloe. "Questions about Identity in International Relations." In International Relations Theory Today, edited by Ken Booth and Steve Smith, 279-305. Cambridge: Polity, 1995.

Zehfuss, Maja. Constructivism in International Relations: The Politics of Reality. Cambridge: Cambridge University Press, 2002.

Zehfuss, Maja. "Constructivism and Identity: A Dangerous Liaison." European Journal of International Relations 7, no.3 (2001): 315-348.

“Dublin European Council Presidency Conclusions, 15 and 16 June 1990.” Accessed April 22, 2014. http://www. europarl.europa.eu/summits/dublin/du1_en.pdf.

"Report by the Foreign Ministers of the Member States on the Problems of Political Unification." Bulletin of the European Communities No. 11 (1970).

"Report by the Reflection Group: A Strategy for Europe.” Accessed March 12, 2014. http://www.ena.lu/report reflection_group_strategy_europe_brussels_december_1995-3-19371.

“Solemn Declaration on European Union, Stuttgart, 19 June 1983.” Accessed February 20, 2014. http://www.ena.lu/ solemn_declaration_european_union_stuttgart_19_june_1983-2-7725.

"Statement Issued by the Heads of State or Government, Bonn." Bulletin of the European Communities 7, no.8 (1961). 